\title{
GIS-based landslide susceptibility assessment in Eyinoke Hilly Area of Okeigbo, SW, Nigeria
}

\section{GBADEBO, AM;*ADEDEJI, OH; EDOGBO, AS}

\author{
Dept. of Environmental Management \& Toxicology, University of Agriculture, PMB 2240, Abeokuta, Nigeria, \\ *Corresponding Author Email: adedejioh@funaab.edu.ng
}

\begin{abstract}
Many areas are exposed to different types of natural hazards including landslides, which can lead to loss of lives, injury to people, damage to property and disruption of economic activities. This paper assessed the landslide susceptibility and quantifies the hazard and risk related to landslides in Okeigbo, southwest, Nigeria using remote sensing imageries, geographic information system (GIS) and logistic regression model. The result revealed that slope, elevation, aspect, profile curvature, distance from road and land use influence landslide susceptibility. Current landslide and the most susceptible areas to landslides were within the areas with high slopes especially at slope angles of landslide occurred on slopes between $14 \%$ and $25 \%$ in the upper, steep and narrow ridge with elevation of between $413 \mathrm{~m}$ and $459 \mathrm{~m}$. The landslide occurred northwest aspect class where there is increased land use activities characterized by deforestation and improper agricultural practices. It was further revealed that the landslide occurred about $200 \mathrm{~m}$ close to the road and potential areas were landslides can occur in the future are closely located within the 100-300 m buffer zones. Generally, Slopes have more influence than land cover for the susceptibility map. Although a smaller portion of the study area is presently located in the high hazard zone, intensive land use activities on the steep slope could expose the land to other triggering factors such as rainfall. A landslide susceptibility assessment and monitoring will assist in prediction, management future occurrences and general developmental planning in the area.
\end{abstract}

\section{DOI: https://dx.doi.org/10.4314/jasem.v22i6.13}

Copyright: Copyright (C) 2018 Gbadebo et al. This is an open access article distributed under the Creative Commons Attribution License (CCL), which permits unrestricted use, distribution, and reproduction in any medium, provided the original work is properly cited.

Dates: Received: 03 June 2017; Revised: 30 May: 2018; Accepted: 15 June 2018

Keywords: Landslide hazard, Vulnerability, Geographical information system; remotely sensed data

Landslide is the slow to rapid downward movement of mass of soil (earth or debris) or rock down a slope (Courture, 2011). It is one of the major natural hazards that cause loss of several of lives and properties especially in the hilly regions of the world. Although individual landslides might not cause such extreme losses as other types of hazards do, but since they occur more frequently the cumulative effect might be more than one would expect (Van Westen, 2004, 2005). Landslides and related processes according to the Centre for Research on Epidemiology of Disasters have killed over 61,000 people world over in the period between A.D. 1900 and A.D. 2009 (EMDAT, 2010). Apart from direct risk that the occurrence of landslide possesses, there are indirect risks to the economic conditions of the society associated with these areas (Remondo, 2008). Researches in landslides has drawn worldwide attention mainly due to increasing awareness of the socio-economic impacts Landslides according to Van Westen (2000, 2012) pose an increasing risk to many countries, closely related to both demographic pressures and territory mismanagement, such as illegal settlements, deforestation and lack of appropriate wastewater management. Studies have shown that landslide occurrence depends on complex interactions among a large number of factors including geologic setting, geomorphic feature, soil property, land cover characteristics, hydrological and human impacts (Dahl et al., 2010; Yeon et al., 2010; Ma et al., 2013. These factors can also be breakdown into two interactive categories: static and dynamic factors. Dynamic factors are the factors that trigger mass movements such as rainfall and earthquakes, while static factors are the determinants of landslide susceptibility, and can be derived from surface characteristics (Sidle and Ochiai, 2006) related to sliding. Landslides often occur on hilly terrains where slope stability has been compromised. Shallow landslides, often called mudslides or debris flows, are rapidly moving flows of mixed rocks and mud that move downhill at speeds of $55 \mathrm{~km}$ per hour or more, kill people and destroy homes, roads, bridges, and other property(Igbokwe et al, 2003). They are caused primarily by prolonged, heavy rainfall on saturated hill slopes (Baum et al. 2002). It is important to carry out landslide hazard assessment as a step towards landslide hazard and risk management (Pradhan and Lee, 2010). The assessment can be used in qualitative risk assessment if there is insufficient information available on past landslide 
occurrences in order to assess the spatial, temporal and magnitude probability of landslides. It can be used to determine the potential areas where landslides can occur and thus mitigation efforts can be planned. Landslide susceptibility mapping have being carried out in many mountainous regions of the world such as India (Melzner et al., 2006; Onagh et al., 2012). Saha et al. (2005) observed that successful prediction of landslide occurrences and the preparation of a map showing landslide-prone areas call for collection of the relevant spatial data. In addition, the reliability of landslide susceptibility maps however depends mostly on the amount and quality of available data, the working scale and the selection of the appropriate methodology of analysis and modelling. In a country like Nigeria, there is the dearth of information on local landslide and slope instability problems and no systematic database on past landslide occurrences is available hence it is often difficult to predict and map landslides.

Due to the diversity and large volumes of data needed, and the complexity in the analysis procedures, quantitative landslide risk assessment has only become feasible in the last decade or so, due to the developments in the field of Geo-Information science (Van Westen, 2012). Extraction of relevant spatial information related to landslide occurrence is an integral part of hazard assessment and advancement in earth Observation (EO) techniques have facilitated effective landslide detection, mapping, monitoring and hazard analysis (Carrara, 1983 and Pike, 2008; Tofani et al., 2013). Remotely Sensed (RS) data combined with Geographical Information System (GIS) are proved to be effective tools for generating and processing spatial information needed for landslide hazard assessment (Van Westen et al., 2003; Yeon et al., 2010; Rotigliano et al., 2011, Tofani et al., 2013; Pacheco and Suárez, 2014). Geographical Information System is widely used in landslide hazard assessment especially for generation of thematic data layers, computation of different indices, assignment of weights, data integration and generation. Moreover, landslide hazard zonation studies in recent times have used digital elevation model (DEM) with high resolution to generate spatial information data layers related to landslide hazards (Dahl et al. 2010; Yeon et al., 2010; Ma et al., 2013). Thematic maps (referred to as data layers in GIS) based on specific parameters or parameters which are related to the occurrence of landslides, such as slope, aspect, lithology, distance to fault, distance to road, distance from river, rainfall, and land cover can be generated.Furthermore, multivariate statistical analysis for landslide hazard zonation considers relative contribution of each thematic data layer to the total landslide susceptibility For instance, logistic regression (LR) has been applied for susceptibility mapping with comparatively high success rates (Chen and Wang, 2007; Erner et al. 2010; Pradhan and Lee, 2010; Ghosh 2011; Xu et al. 2012). Logistic Regression is useful for predicting the presence. or absence of a characteristic or outcome based on values of a set of predictor variables. For landslide susceptibility mapping, the LR model find the best fitting model to describe the relationship between presence and absence of landslides and the set of independent variables such as slope angle, slope aspect, lithology and land use (Guzzetti et al., 1999; Gorsevski et al., 2000; 2005). It generates the model statistics and coefficient of formulae useful in defining susceptibility. If coefficient is positive, the landslide event is likely to occur.

The main data layers required for landslide susceptibility, hazard and risk assessment could be subdivided into four groups: landslide inventory data, environmental factors, triggering factors, and elements at risk (Van Westen et al., 2005). The landslide inventory, which is by far the most important, is often not available in countries like Nigeria. No map or guideline currently exists to assess the relative landslide potential hence, people are caught unaware and there are often no mitigation efforts by the government. In hilly terrains of Nigeria such as Okeigbo in the southwestern region, heavy rainfall, porosity of the soil and moisture content as well as slope angles facilitates the occurrence of landslide recently, which destroyed lots of properties and infrastructures. Residents are now grip with the palpating fear that every time it rains the slope will give way again, especially with the massive urbanization and agricultural practices along the slope that makes the land prone to landslides. In view of the considerable losses due to landslides, there is the need to take into account occurrence of landslides, and find ways to mitigating the ensuing losses and consequences (Abella, 2008; Onagh et al., 2012). Therefore, this study evaluated the occurrence of landslide in the study area and predicted future occurrence to assist decision-making, land development and planning for sustainable development in the area.

\section{MATERIALS AND METHOD}

Study area: Okeigbo is a growing urban settlement situated in the western part of Ondo State, Nigeria sharing boundaries in the east with Ondo and Ifedore Local Government Areas of Ondo State and in the west with OsunState. The community lies between longitude $4^{\circ} 11^{\prime} \mathrm{E}$ and latitude $7^{\circ} 10^{\prime} \mathrm{N}$. It is a heterogeneous community, consisting of people from the Yoruba speaking groupsand people from different 
parts of the country. The regional geology of Ondo state in which the study area is a part consists of the two major rock types viz: the basement complex rocks of pre-Cambrian age and the sedimentary rocks of cretaceous to Recent Age. The rocks consist of migmatite gneiss complex, meta-sediments and older granites. It is also very rich in quartzite, which form ridges and have undergone series of tectonic activities. The quartzites, which are in block forms, are exposed in most of the locations due to weathering and erosion.

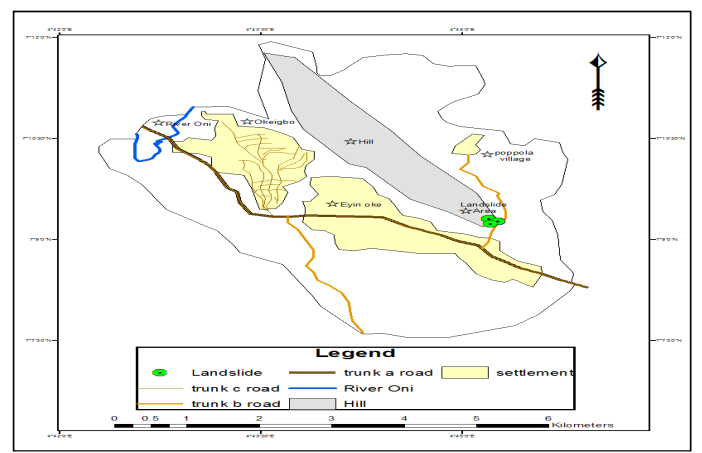

Fig1: Map showing the study area

Data source: The methods and working procedure utilized in the present study generally follow those of Lee et al. (2008). The first step involves the acquisition of satellite images and data collection.A $30 \mathrm{~m}$ by $30 \mathrm{~m}$ spatial resolution Landsat 8 ETM+ imagery (Path 190 and Row 55) of 2014 was obtained from Global Land Cover Facility (University of Maryland, USA). In addition, field data was collected from the study area to obtain first hand information on the current landslide. The geologic and topographic maps are projected with the Minna national UTM datum, while the Landsat-ETM+ dataset used the WGS-84 datum. Later each map was reprojected to a common datum, using applications and transformation parameters available in commercial software as ArcGIS and Erdas Imagine.Digital elevation model (DEM) data set was obtained from the National Aeronautics and Space Administration (NASA) Shuttle Radar Topography Mission (SRTM; http://www2.jpl.nasa.gov/srtm/) dataset.The Shuttle Radar Topographic Mission (SRTM) image data of 2002 covering the study area was used to generate the DTM at $10 \mathrm{~m}$ interval. The DEM data was used to derive topographic factors such as elevation, slopes, aspects, hill shading and slope curvature. These criteria are proven predisposing factors for landslide activity in the study area. Erdas Imagine 10.0. and ArcGIS v. 9.3 GIS software were used to produce the layer maps that assist in production of landslide susceptibility maps. High-resolution image of the study area obtained from Google Earth Archives was used to digitize landslide, inventories and other features such as buildings, rivers, roads, etc. The coordinates of important points like road conjunction points and landslide prone area were measured during the field surveys using Global Positioning Systems (GPS) technology. These together with the field data were integrated into the demarcated image to generate a detailed classified landslide susceptibility data.An event-based landslide inventory was then established, the causative factors of the landslides are processed, and the triggering factors determined. These factors are then statistically tested, and the effective factors selected for susceptibility analysis. The flowchart showing the working procedure is shown in Figure 2.

Image Processing: The Landsat 8 (ETM+) layers (band) were stacked and subset to delineate the study area for classification and processed into false colour composite (FCC) using the 3 bands (543) (Figure 2).

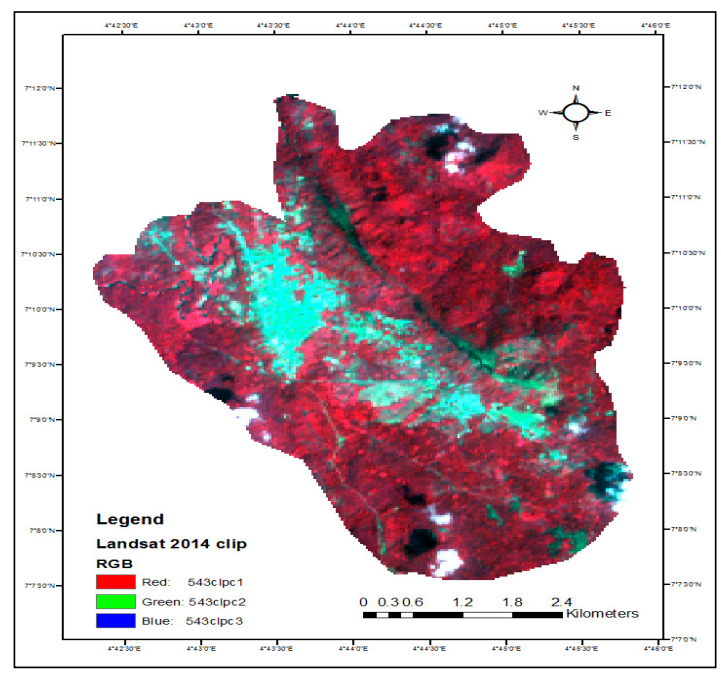

Fig2: False Colour Composite (Bands 543) of Landsat ETM+ 2014 of the study area

A Principal Component Analysis (PCA) was performed on the image in order to reduce data redundancy. The UTM Zone $31^{\circ} \mathrm{N}$ Coordinate on the WGS 84 was used to geocode the imported image. This was followed by re-sampling of the image using Longitude/latitude coordinates. The georeferencing was quite accurate as verified by the fact that when a portion of the study area administrative map was superimposed on to the ETM+ image, it produced a near accurate fit. A number of thematic maps (referred to as data layers in GIS) based on specific parameters (slope, aspect, elevation, profile curvature, distance to fault, distance to road, distance from river, rainfall, and land cover), which are related to the occurrence of landslides were generated.These causative factors and triggering factors were used to build a landslide 
susceptibility model via logistic regression. Validation result shows that this model could be used for the prediction of future landslides.

Slope:The slope angle is directly related to the landslides, it is frequently used in preparing landslide susceptibility maps. For this study, the slope angle was considered as a major parameter of the slope stability. Slope is commonly used in preparing landslide susceptibility analyses (Yalcin 2008) as the shear stress increases with progressive inclination. Slope is the measure of surface steepness and measured in degrees. It has a range between 0 and $90^{\circ}$, where $0^{\circ}$ represents the flat and $90^{\circ}$ represents the vertical areas. Slope angle is important in landslide susceptibility studies because landsliding is directly related to slope angle. The slope map of the study area was divided into 9 slope categories.

Aspect: The layer for aspect was also based on the DEM. It represents the angle between the Geographic North and horizontal plain for a certain point and is classified by 8 major orientations The aspect of the study areas were classified into 8 classes including the flat areas as: flat $\left(-1^{\circ}\right)$, north $\left(0^{\circ}-22.5^{\circ}\right)$, North-East $\left(22.5^{\circ}-67.5^{\circ}\right)$, east $\left(67.5^{\circ}-112.5^{\circ}\right)$, South-East $\left(112.5^{\circ}-157.5^{\circ}\right)$, south $\left(157.5^{\circ}-202.5^{\circ}\right)$, South-West $\left(202.5^{\circ}-247.5^{\circ}\right)$, west $\left(247.5^{\circ}-292.5^{\circ}\right)$ and NorthWest $\left(292.5^{\circ}-337.5^{\circ}\right)$. Aspect is an important factor in preparing landslide susceptibility maps (Lee 2005; Yalcin 2008; Ercanoglu and Temiz, 2011).

Profile curvature: Profile curvature represents the rate of change of slope for each cell in the direction of dipping. Profile curvature is divided by concave, convex and flat topographic surfaces. A positive curvature indicates that the surface is upwardly convex at that cell. A negative curvature indicates that the surface is upwardly concave at that cell.

Distance from road: Distance from the road is an important factor that can trigger the occurrence of landslides. Roads construction influences the density of landslides, especially in sloping areas where road cuts are made (Pachauri et al., 1998; Yalcin, 2005). Roads constructed along slopes may cause decrease in the load on both the topography and on the heel of the slope. Five different buffer areas were created on the path of three classes of roads in the area to determine the effects of road on the stability of slope.

Land use/Land cover: Land use is another factor responsible for triggering the occurrence of landslides. Generally, slopes without vegetal cover and disturbed forests are more prone to landslides in contrast to vegetative areas that tend to reduce the action of climatic agents such as rain, etc., thus preventing the erosion due to the natural anchorage provided by the tree roots. Land cover map of the area was prepared using 2014 Landsat ETM+ of in the GIS environment. Settlement (built-up), Forest and agriculture are the main land cover classes in the study area, however, increase urbanization has encroached into the forested area as more lands are denuded and exposed to climatic elements. Generally, slopes with dense vegetation cover should be less prone to the occurrence of shallow landslides than barren slopes, while all other parameters remain constant.

Image Classification: Supervised classification of the 2014 Landsat ETM+ image was carried out using the Maximum Likelihood Classifier Technique (algorithm) in ArcMap 10.0, where the classification is based on the aggregation of the classes depending on the spectral reflectance. Supervised classification uses the spectral signatures obtained from training samples to classify an image. Five major land use/land cover classes were identified from the images, namely: bare ground, thick forest, disturbed forest, agriculture and built-up.

Inventory map: The identification and mapping of existing landslide is prerequisite to perform statistical analysis on the relation between the distribution of landslides and influencing parameters (Saha et al. 2005). A Landslide Inventory Database of the study area was prepared by visual interpretation of Google Earth image, Landsat TM (2002) and Landsat ETM+ of 2014 and field survey. The main scarp of the recent landslide was depicted in topographic maps at a proper scale and then was digitized as polygon layer.

Selection of Factors for Modelling: There are more than fifty different landslide-related factors commonly used worldwide for LSA (Lin, 2003). In this study, six (6) causative factors: slope, aspect, elevation, profile curvature, distance to road, and land cover were selected for building the susceptibility model.

\section{RESULTS AND DISCUSSION}

Elevation: Topography is one of the most important factors in landslides susceptibility assessment and the study revealed that the present landslide occurred in the area with elevation of between $413 \mathrm{~m}$ and $459 \mathrm{~m}$. The area very steep

Slope; The slope angle represents the gravitational force component and as such regulates mobilization vectors within a hill slope (Catani et al., 2005). Studies have shown that landslides mostly occur at certain critical slope angles (Uromeihy and Mahdavifar 2000). 
The transverse slope profile is an important variable that controls the superficial and subsurface hydrological regime of the slope (Zezere et al., 2004).The slope values in the study area range between $0^{\circ}$ and $82^{\circ}$. The slope of the study area was divided into nine slope angle categories in order to more accurately represent site conditions (Fig.3b). The most recent landslide in the study area occurred at a 14 $\%$ and $25 \%$ in the upper, steep and narrow ridge Materials made up of rock debris mixed with mud transported down slope after the prolonged rain the weakened the slope.

Aspect: In this study, the aspect map of the study area was produced from the DEM to show the relationship between aspect and landslide. The current landslide occurred northwest aspect class, which is also related to slope angle (Fig.3c). Aspect is related to parameters such as exposure to sunlight, winds (dry or wet), rainfall (degree of saturation), soil moisture and discontinuities may control the occurrence of landslides (Dai et al., 2001).

Profile curvature: Profile curvature represents the rate of change of slope for each cell in the direction of dipping. Profile curvature is divided by concave, convex and flat topographic surfaces. A positive curvature indicates that the surface is upwardly convex at that cell. A negative curvature indicates that the surface is upwardly concave at that cell. A value of zero indicates that the surface is relatively flat (Fig.3d).

Distance from road: The present landslide occurred about $200 \mathrm{~m}$ close to the road to Popoola village and potential areas were landslides can occur in the future are closely located within the $100-300 \mathrm{~m}$ buffer zones(Fig.3e).

Land use/Land cover: According to the land cover classes the present landslide occurred in the barren slope where human activities is on the increase (Fig. 3f) Changes in land cover and land use resulting from human activities, such as deforestation, forest logging, road construction, fire and cultivation on steep slopes can have an important impact on landslide activity (Cannon, 2000). Vegetal cover have effects on the hydrological processes of shallow landsliding which can be subdivided into the loss of precipitation by interception, removal of soil moisture by evapotranspiration and the effects on hydraulic conductivity (Van Beek, 2002; Wilkinson et al., 2002).

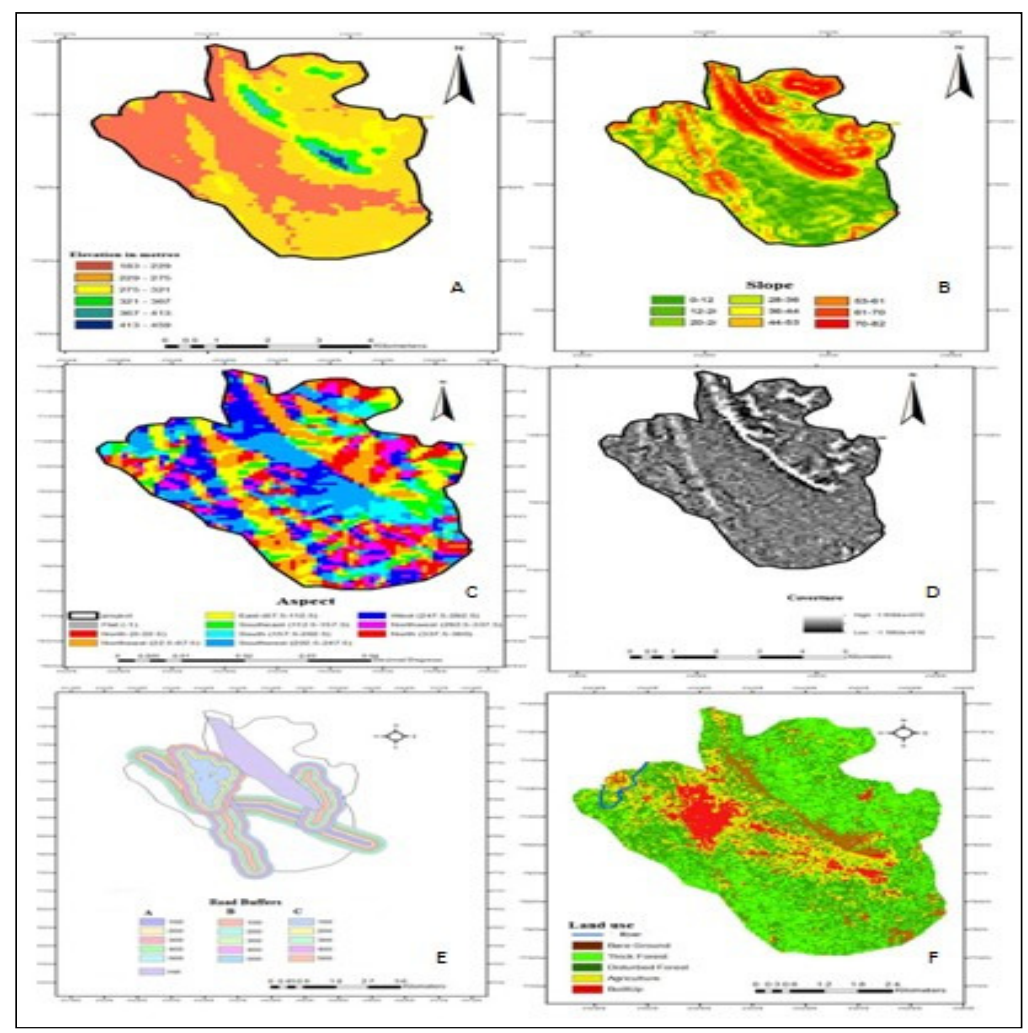

Fig3: Vector maps of the factors affecting landslides in the study area 
Logistic Regression:Landslide causative factors and triggering factors were used to build a landslide susceptibility model via logistic regression.Logistic regression (LR) allows us to determine a linear function of factors for interpreting the landslide distribution from a set of training data. The methodology has successfully applied in many previous studies of landslide susceptibility (Ayalew \& Yamagishi, 2005). Logistic regression (LR) relates the probability of landslide occurrence (having values from 0 to 1 ) to the "logit" $\mathrm{Z}$ (where $-1<\mathrm{Z}<0$ for higher odds of non-occurrence and $0<Z<1$ for higher odds of occurrence). In the LR formulae, the probability of landslide occurrence is expressed by:

$P_{r}=e^{z / 1} 1+e^{z}=1 / 1+e^{-z} \quad \cdots \cdots \cdots \cdots \cdots \cdots \cdots \cdots \cdots \cdots \cdots \cdots \cdots \cdots \cdots \cdots$

The logit $\mathrm{Z}$ is assumed to contain the independent variables on which landslide occurrence may depend. The LR analysis assumes the term $\mathrm{Z}$ to be a combination of the independent set of geographical variables $\mathrm{Xi}(\mathrm{i}=1,2, \ldots, \mathrm{n})$ acting as potential causal factors of landslide phenomena. The term $\mathrm{Z}$ is expressed by the linear form:

$Z=\beta 0+\beta 1 X 1+\beta 2 X 2+\cdots .+\beta n X n \ldots \ldots \ldots .2$

Where coefficients $i(i=1,2, \ldots, \mathrm{n})$ are representative of the contribution of single independent variables $X i$ to the $\operatorname{logit} Z$ and 0 is the intercept of the regression function. It must be noted that the LR approach does not require, or assume, linear dependencies between dependent term of Prand the independent set of variables representing causal factors. An exponential equation and coefficients are estimated using maximum likelihood criterion and correspond to the estimation of the more likely unknown factors.

Prediction of landslide susceptibility: Multivariate regression analysis plays a central role in statistics that cause one of the most powerful and commonly used techniques (McCullagh and Nelder, 1989). Multivariate regressions method in SPSS software was used with six factors including elevation, slope, aspect, profile curvature, proximity to road and land use against 22 homogeneous units. In this method, independent variables were entered based on its correlation with depend variable which is landslide susceptibility (Equations 3 and 4). Variables with greater correlation are entered earlier and variables with lower correlation were eliminated.

$Z=0.317+0.214 E-0.038 A+0.66 S+0.118 R B+13.208 L U 3$

$L S_{P r e}=1 / 1+\mathrm{e}^{(0.317-0.214 E-0.038 A-0.066 S-0.118 R B-13.2082 L U)} \ldots .4$
Where : is Napierian logarithm, LSPre: is predicted landslide susceptibility, $E$ is: Elevation, $S$ :is Slope, $R B$ : is Road Buffer, $L U$ : is Land Cover, and $A$ : is Aspect.

All GIS analysis was performed with ArcMap 10.0, which is public domain raster-based GIS software. However, the SPSS statistical package was employed for the LR analysis.

Table 2 : Predictors: (Constant), Land Use, Road Buffer, Aspect, Slope, Elevation

\begin{tabular}{lllll}
\hline Model & $\mathrm{R}$ & $\mathrm{R}^{2}$ & Adjusted $\mathrm{R}^{2}$ & $\begin{array}{l}\text { Std. Error of } \\
\text { the Estimate }\end{array}$ \\
1 & $0.947^{\mathrm{a}}$ & 0.897 & 0.864 & 0.27858 \\
\hline
\end{tabular}

Table 2 above shows the regression analysis based on the six causative factors of landslide in the study area. This table provides the $\mathrm{R}, \mathrm{R}^{2}$, adjusted $\mathrm{R}^{2}$, and the standard error of the estimate, which can be used to determine how well a regression model fits the data. The " $R$ " column represents the value of $R$, the multiple correlation coefficient. $\mathrm{R}$ can be considered as a measure of the quality of the prediction of the dependent variable; in this case, Landslide Susceptibility. A value of 0.947 indicates a good level of prediction. The " $\mathrm{R}^{2}$ " column represents the $\mathrm{R}^{2}$ value (also called the coefficient of determination), which is the proportion of variance in the dependent variable that can be explained by the independent variables (technically, it is the proportion of variation accounted for by the regression model above and beyond the mean model). From the analysis, the value of 0.897 , which is the independent variables, explain $89.7 \%$ of the variability of the dependent variable,Landslide Susceptibility.

To test whether the regression model is good for the data, a one-way analysis of variance wasperformed

Table 3. Analysis of Variance

\begin{tabular}{llccccc}
\hline Model & $\begin{array}{c}\text { Sum of } \\
\text { Squares }\end{array}$ & df & $\begin{array}{c}\text { Marn } \\
\text { Square }\end{array}$ & F & Sig. \\
\hline 1 & Regression & 10.758 & 5 & 2.152 & $27.7260 .000^{\circ}$ \\
& Residual & 1.242 & 16 & 0.078 & & \\
& Total & 12.000 & 21 & & & \\
\hline
\end{tabular}

Table3 shows that the independent variables significantly predicted the dependent variable, hence, the regression model is a good fit of the data. The analysis show that elevation, aspect, slope, profile curvature, distance from road and land useinfluence landslide susceptibility.

Landslide susceptibility map: Figure 4 below shows the final landslide susceptibility map of the study area. Landslide Susceptibility map was produced based on the selected factors (Figure 4). From the map, the green area predicts areas with low landslide 
susceptibility, the light blue shade predicts moderate susceptibility and the deep blue shade predicts high susceptibility of landslide. The result shows that current landslide and the most susceptible areas to landslides are within the areas with high slopes. Human activities such as deforestation, farming and settlement expansion contribute to incidences of landslides in the area. In these areas, the impact of rainfall induced flood water is high and slope failures are very predominant. There are also wide spread occurrence of deep and wide gullies in this area, as more and more sloppy grounds can cave in after being weakened by the impact of rainfall. Areas that are of average, less or least susceptibility are found mainly in the low-lying grounds.

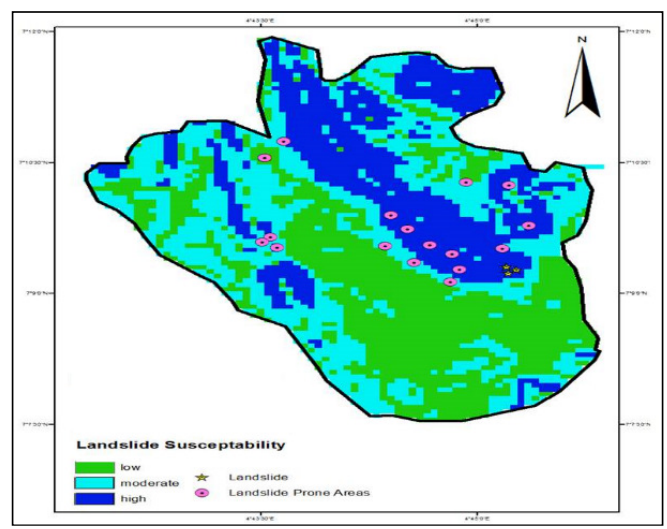

Fig4: Landslide susceptibility map of the study area

Validation of landslide susceptibility map: To validate the accuracy of the landslide susceptibility map, observed landslides,slope map, Land-use land cover map and susceptibility map were compared. It was evident in thatlandslide occurred in areas with steep slope and high land usage characterized by deforestation and improper agricultural practices, in the study area.

Conclusion: Although, landslide inventory covering the study area is not available the study revealed that the present landslide occurred on slopes between $14 \%$ and $25 \%$. There is no observed landslide in slopes greater than 25 percent. It is because of the fact that in very steep slopes the soil depth and its load are decreased. The landslide has occurred in north and west aspects, which is due to angle of sun radiation and soil moisture condition. The rate of landslide can increase with higher elevations. However, in elevation ranging, from zero to 291 meters landslide occurrences may be related to land-use change, which is crop in lower lands to forest in upper lands. Analysis of the observed landslide indicated that most of events have occurred near or close to the roads. This may due to development activities and constructing roads with deep trenches. It is important to assess landslide risks and incorporated this as part of policy planning and actions. Deforestation is not an unstoppable or irreversible process. Increased and concerted efforts in forest plantation 'rebirth' and rejuvenation will reduce pollution and environmental degradation. In view of the spatio-temporal changes in the land use and land cover of the study area and its effects on the biodiversity, the following recommendations should be adopted for policy makers for better decisionmaking.

\section{REFERENCES}

Abella, E (2008). Multi-scale landslide risk assessment in Cuba. International Institute for Geo-Information Science and Earth Observation. Enschede, the Netherlands

Ayalew, L; Yamagishi, H (2005). The application of GISbased logistic regression for landslide susceptibility mapping in the Kakuda-Yahiko Mountains, Central Japan. Geophys J Roy Astron Soc, 65:15-31

Baum, RL; Savage, WZ; Godt, JW (2002). TRIGRS - A FORTRAN program for transient rainfall infiltration and grid-based regional slope-stability analysis: U.S. Geological Survey Open-File Report 02-0424, 64pp.

Carrara, A; Pike, RJ (2008). GIS technology and models for assessing landslide hazard and risk. Geomorphology, 94: $257-260$.

Catani, F; Casagli, N; Righini, G; Menduni, G (2005). Landslide hazard and risk mapping at the catchment scale in the Armo River basin, Landslides, 2: 329-342.

Courture, R (2011).Landslide Terminology - National Technical Guidelines and Best Practices on Landslides. Geological Survey of Canada. p 12, Open File 6824

Dahl, M; Mortensen, L; Veihe, A; Jensen, N (2010). A simple qualitative approach for mapping regional landslide susceptibility in the Faroe Islands. Nat Hazards Earth Syst. $\quad$ Sci. 10:159-170

Dai, FC; Lee, CF (2002). Landslide characteristics and slope instability modelling using GIS, Lantau Island, Hong Kong. Geomorphology 42:213-238

EMDAT (2010) Emergency Disasters Data Base, Volume 2010: Brussels, Belgium, Centre for Research on the Epidemiology of Disasters. Ecole de Santé, Publique Université Catholique de Louvain

Ercanoglu and Temiz (2011). Application of logistic regression and fuzzy operators to landslide susceptibility assessment in Azdavay (Kastamonu, Turkey). Environ Earth Sci. 64:949-964 
Ghosh, S (2011). Knowledge Guided Empirical Prediction of Landslide Hazard. University of Twente, Netherland

Gorsevski, PV; Gessler, P; Foltz, RB (2000). Spatial Prediction of Landslide Hazard Using Discriminant Analysis and GIS. Proceedings of GIS in the Rockies 2000 Conference: Applications for the 21st Century. Denver, Colorado. September 25 - 27, 2000.

Guzzetti, F; Carrara, A; Cardinali, M; Reichenbach, P (1999). Landslide hazard evaluation: a review of current techniques and their application in a multistudy, Central Italy. Geophys J Roy Astron Soc, 31:181-216

Igbokwe, JI; Ojiako, JC; Nnodu, VC (2003). Monitoring, Characterisation and Controlling of Floodwater Erosions Using Remote Sensing Techniques. Proceedings of the Technical Session of 38th Annual Conference of Nigerian Institution of Surveyors, Lokoja, Nigeria, pp. $73-79$

Lee, S.,(2005). Application and cross-validation of spatial logistic multiple regression for landslide susceptibility analysis. Geoscience, 9, 63-71.

2008). Statistical approach to storm event-induced landslide susceptibility. Natural Hazard and Earth System Sciences, 8, 941-960.

Lin, YH. (2003). Application of neural networks to landslide susceptibility analysis. M.S. Thesis of Institute of Applied Geology, National Central University. (in Chinese with English abstract)

Ma F, Wang J, Yuan R, Zhao H, Guo J (2013) Application of analytical hierarchy process and least square method for landslide susceptibility assessment along the Zhong - Wunatural gas pipelines. China Landslides Doi:, Doi: 10.1007/s 10346-013-0402-8

McCullagh, P., Nelder, J.A. (1989). Generalized Linear Models (Monographs on Statistics and Applied Probability. Chapman \& Hall, London, Second Edition, 532 pages.

Melzner, S., T. Glade and M. Bonte-Grapentin (2006). Landslide Susceptibility Analysis Using Remote Sensing Derived Data and GIS Techniques - Navua Catchment, South Viti Levu, Figi Islands.

Onagh, M., Kumra, V.K. and Rai, P.K. 2012. Landslide susceptibility mapping in a part of uttarkashi district (india) by multiple linear regression method. Inter. J. Geol. Earth. Environ. Sci. 2 (2.102-120

Pacheco, H; Suárez, C. (2014). Geographic Information Technologies for the Study of Mass Wasting Hazards. International Journal of Geosciences, 5, 519-526

Pradhan, B; Lee, S. (2010). Regional landslide susceptibility analysis using backpropagation neural network model at Cameron Highland, Malaysia. Landslides, 7:13-30
Saha, AK; Gupta, RP; Sarkar, I; Arora, MK; Csaplovics, E (2005). An approach for GIS-based statistical landslide susceptibility zonation - with a case study in the Himalayas, Landslides. 2, pp. 61-69

Remondo, J; González, A; Ramón, J; Cendrero, A; Fabbri, A.; Chung, CJF. (2003). Validation of landslide susceptibility maps: examples and applications from a case study in Northern Spain. Natural Hazards 30, 437449

Rotigliano, E; Angesi, V; Cappadonia, C; Conoscenti, C (2011). The role of diagnostic areas in the assessment of landslide susceptibility model: a test in the Sicilian chain, Italy. Nat Hazards, 58:981-999

Sidle, RC; Ochiai, H. (2006). Landslide processes, prediction, land use. American Geophysical Union, Washington, DC, pp 1-312

Tofani, V; Segoni, S; Agostini, A; Catani, F; Casagli, N (2013). Use of remote sensing for landslide studies in Europe. Nat Hazards Earth Syst. Sci. 13:299-309

Uromeihy, A; Mahdavifar, MR (2000). Landslide hazard zonation of Khorshrostam area, Iran. Bull Eng Geol Environ., 58:207-213.

van Westen, CJ;van Asch, TWJ; Soeters, R (2005). Landslide hazard and risk zonation; why is it still so difficult? Bull. Engineer. Geol. Environ.65 (2), 167184.

Wilkinson, PL; Anderson, MG; Lloyd, DM; Renaud, JP(2002). Landslide hazard and bioengineering: towards providing improved decision support through integrated numerical model development. Environ. Model. Software. 17 (4), 333-344.

Xu, C; Dai, F; Xu, X; Lee, Y (2012). GIS-based support vector machine modeling of earthquake-triggered landslide susceptibility in the Jianjiang River watershed, China. Geophys J Roy Astron Soc, 145146:70-80

Yalcin, A (2008). GIS-based landslide susceptibility mapping using analytical hierarchy process and bivariate statistics in Ardesen (Turkey): Comparisons of results and confirmations. Catena, 72: 1-12.

Yeon, Y; Han, J; Ryu, K (2010). Landslide susceptibility mapping in Injae, Korea using a decision tree. Engineer. Geol. 166:274-283

Zezere, JL; Reis, E; Garcia, R; Olieira, S; Rodrigues, ML; Vieira, G; Ferreira, AB (2004). Integration of spatial and temporal data for the definition of different landslide hazard scenarios in the area north of Lisbon (Portugal), Natural Hazards and Earth Sys. Sci. 4: 133146. 